\title{
A modest contribution to security and cooperation
}

TUCKED away among the fifty pages of the Helsinki Agreement is a short paragraph envisaging a 'scientific forum'-_"a meeting of leading personalities in science from the participating states". In the two years after Helsinki, this item seems to have been given little attention. But amidst the wrangling at Belgrade last year, it was a relief to agree to set up an innocuous meeting of experts to plan the forum.

This meeting took place in Bonn, during the summer. For six whole weeks, diplomatic and scientific representatives of the 36 signatories of the Final Act of the Conference on Security and Cooperation in Europe (CSCE-alias the Helsinki 'Agreement')-circled warily and delicately around this modest-seeming proposal. Their eventual report was unanimous: the scientific forum will be held in Hamburg, in February 1980.

From the diffuse agenda proposed in this report it is difficult to estimate the significance of the forum. Two weeks of discussions of "interrelated problems of common interest concerning current and future developments in science" are not likely to throw much new light on the human condition, especially when dispersed over such a diversity of topics as "alternative energy sources", "food production", "trends in medical research, in particular in basic research and primarily on cardiovascular, tumour and virus diseases, taking into consideration the influence of the changing environment on human health", and "comparative studies on social, socio-economic and cultural phenomena, especially the problems of human environment and urban development".

In the diplomatic bargaining that produced this list, it was obviously easier to achieve a consensus by including the favourite topic of every delegation than to spend another six weeks trimming it down to size. Thousands of man-weeks of serious discussion of all these topics is already taking place each year, uninhibitedly across all the frontiers of the world; nobody is under any illusions that the forum can do much more scientifically than skim lightly over very familiar ground.

The original text of the CSCE Final Act intends that the forum should "promote the expansion of contaots, communications and the exchange of information, between scientific institutions and among scientists". But here again, a meeting of this kind can do little to supplement the existing network of bilateral and multilateral agreements, involving national scientific organisations, transnational scientific

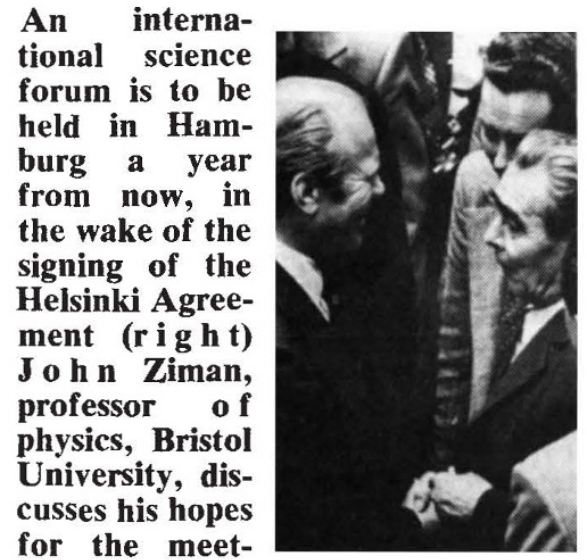

ing.

unions, and international agencies, under which such activities already take place on a very large scale. In this respect, the further implementation of the Helsinki Agreement to improve cultural and scientific contacts depends essentially on the amelioration of the general political climate and on detailed attention to a multitude of small obstacles to free traffic in ideas and people.

Nevertheless, those of us who took part in the Bonn meeting came to appreciate the value of the proposed forum as a symbol of the Helsinki spirit, with a modest potentiality for good, both for the progress of science and for the welfare of the people of Europe. In the acrimonious aftermath of Belgrade, it was natural that the proceedings at Bonn were ponderous, and the agreed agenda turned out to be rather trite. This was a diplomatic meeting, with all the rigmaroles of achieving complete agreement amongst the representatives of sovereign states.

If the scientists had been left alone to plan the forum, they might not have been quite so sensitive to the protocols of arriving at consensual proposals within the interlacing alliances of the 'nine' (the EEC) and the 'fifteen' (NATO). Even where there is sharp conflict of interest, as between the countries of the Soviet bloc and the Western democracies, scientific leaders can usually rely upon the shared experiences and common goals of research, so that negotiations of this kind are seldom conducted at arm's length.

But behind the courteously meandering debates and apparently trivial verbal amendments of text lay real issues, which might well have been compromised in a less self-conscious bargaining process. What is science? Is it the technological arm of state power, or does it transcend national frontiers? Should those 'leading scientific experts' who are to participate so gravely in the forum be cast as official representatives of their respective governments, or should they appear as individuals supported by the authority of their scholarly achievements? Are the topics to be treated largely from the aspect of practical application-hence within all the constraints of economic, political and military competition-or in those fundamental aspects that are universal and free for all mankind? These questions were a constant preoccupation of the diplomatic and scientific representatives at Bonn, on both sides of the Great Divide.

On the whole, the agenda of the forum leaves the door as open for truth as for the manifestations of power. This is something of an achievement. From the beginning, the Soviet government and its closest allies were fearful that the West might be tempted to use the forum as an instrument of protest against the oppression of dissidents. Their desire to impose official representative status on the speakers at the forum was as much an attempt to muzzle such 'undiplomatic' mouthpieces as a reflection of their own heavily bureaucratised and subservient scientific systems. The Bonn report does not impose such a gag, thus effectively recognising the universality of the voice of science.

In my view, it would be a mistake for Western scientists to press the human rights issue at the forum. This I say reluctantly, for this issue is profound within modern science. But what is offered at Hamburg, in little more than a year's time, is the opportunity to celebrate, under official governmental auspices, as publicly and as explicitly as could be, the genuinely transnational character of the scientific enterprise. It will be an occasion to demonstrate the universality of empirical fact and rational argument, the communal spirit that pervades research work in all fields, the fraternity and cosmopolitanism of the republic of learning, and the humane benefits that accrue from a body of reliable scientific knowledge. These are the norms to which we refer, these are the ideology of science itself - the ideology to which the dissidents themselves appeal in their opposition to tyranny.

The Helsinki Agreement was about cooperation and détente. The true meaning of these unhappily tattered concepts in the scientific and cultural domain must not be forgotten. The value of the scientific forum is unlikely to be found in deeper understanding of technical scientific issues, nor in another confrontation on sociopolitical fundamentals, but perhaps in a modest affirmation that truth itself is one of the powers to be reckoned with in the real world. 